Модерна доба

УДК 658.6.9:639.12(477.83/.86)«18/19»

DOI https://doi.org/10.32836/2309-7205-2018-1-2-17-18-3

\title{
ВПЛИВ МИТНОЇ ПОЛІТИКИ ВЛАДИ ГАЛИЧИНИ СЕРЕДИНИ ХІХ - ПОЧАТКУ ХХ СТОЛІТТЯ НА МИСЛИВСЬКЕ ТА РИБАЛЬСЬКЕ ГОСПОДАРСТВО
}

\author{
О. Р. Проців
}

(Львівський регіональний інститут державного управління Національної академії державного управління при Президентові України, м. Львів)

Органи держсавної влади Галичини для впорядкування організаиії мисливського та рибальського господарства видали низку нормативно-правових актів, якими врегульовували мита під час проведення зовнішньо-торгівельних операщій. Висвітлено рівень митних зборів продукиії мисливства та рибальства під час експортно-імпортних операцій. Проведено історичний аналіз митних зборів із продукцї̈ мисливства та рибальства Галичини середини XIX - початку XX cm. Здійснено порівняльний аналіз мита на мисливські та свійські тварини. Проаналізовано правозастосування вимог законодавства щодо адміністрування митних зборів органами держсавного управління Галичини.

Ключові слова: державне регулювання, торгівля, мито, полювання, дичина, АвстроУгорська імперія.

$O$. R. Protsiv. Influence on hunting and fishing of the customs policy of the authorities of galicia in the middle of the 19th - beginning of the 20th century

The public authorities of Galicia have issued a number of regulatory acts, which regulated duties in the conduct of foreign trade operations to regulate the organization of hunting and fishing. The main laws defining the customs policy in the Austro-Hungarian Empire are described: "On customs" (1868), "On the import customs tariff of Austro-Hungary" (1882), "On the establishment of the duty" (1906). Also intergovernmental agreements of the Austro-Hungarian Empire are described, which regulated export-import operations with European countries. The position of countries regarding lobbying of interests in conclusion of agreements is highlighted. The analysis of activity of public organizations and their influence on the customs policy of the states is carried out. The methods of manipulation in protecting the interests of the beneficiaries are described. A comparative analysis was carried out on the volume of export and import of hunting products and fish of the Austro-Hungarian Empire with other European countries, namely: Germany, Russia, Italy, Switzerland, France. The volume of export and import of hunting products of Galicia in Austro-Hungarian Empire is covered. The article analyzes the movement of products from game and fish within the empire and analyzes the influence of customs policy on the formation of prices on the domestic markets of Austria-Hungary and Galicia. The methods of transportation in the organization of export-import operations are described. The analysis of veterinary aspects, quality of hunting products and fish during trade is carried out. Cases of abuse of officials at the customs authorities in the performance of their official duties are described. The national traditions in consumption of products of hunting and fishing and their influence on the price and formation of the customs policy are highlighted.

The level of customs duties on hunting and fishing products during export-import operations is highlighted. It was made historical analysis of customs duties on products of hunting and fishing of Galicia in the middle of the 19th till beginning of the 20th century. A comparative analysis of fees for hunting and domestic animals was carried out. The law enforcement application of the legislation on the administration of customs duties by the public authorities of Galicia is analyzed.

Key words: state regulation, trade, duty, hunting, game, Austro-Hungarian Empire.

(C) О. Р. Проців, 2018 
Постановка проблеми. На цей час в Україні не врегульовано механізм справляння митних зборів із продукції полювання та рибальства, який би відповідав сталому розвитку галузі. Дослідження цієї проблеми в історичному контексті дасть змогу врахувати місцеві особливості в даній сфері.

Аналіз останніх наукових досліджень і публікацій. Проблема правового регулювання, економічної, соціальної, політичної, гуманітарної складової частини забезпечення Галичини продукцією полювання досліджувалась низкою науковців, серед яких: Ф. Рожинський, С. Павлік, К. Кохановський, Я. Дерзіньський.

Мета статті полягає в тому, щоб дослідити вплив митної політики влади Галичини середини XIX - початку XX століття на мисливське та рибальське господарство.

Для досягнення поставленої мети потрібно вирішити такі завдання:

- провести аналіз чинних у вказаний час нормативно-правових актів Галичини, міністерств Австро-Угорської імперії;

- дослідити політичне, соціально-економічне значення реалізації дичини в досліджуваний період;

- визначити розвиток державного регулювання митних зборів під час торгівлі дичиною та рибою у Галичині середини XIX - початку XX ст.

Органи державної влади Галичини та Австро-Угорської імперії здійснювали публічне управління умовами торгівлі дичиною та рибою з іншими країнами. Головним регулюючим механізмом зовнішньо-економічних відносин була сплата мита під час експортно-імпортних торгівельних операцій. Як показує аналіз правового забезпечення торгівлі дичиною та рибою, держава через митні платежі здійснювала наповнення бюджету.

Тогочасна статистика свідчить, що в період із 1884 до 1908 р. Австро-Угорщина імпортувала дичину на суму 1701082 крони, тоді як експортувала на суму 73090307 крон, тобто експорт дичини переважав імпорт. Найбільше дичини імпортували до Австро-Угорщини з Німеччини (54,82\%), Росії $(23,14 \%)$ та Італії $(16,06 \%)$. Найбільший експорт дичини з Австро-Угорщини відбувався до Німеччини (42,3\%), Швейцарії (21,55\%) та Франції (20,81\%). Загалом за період з 1884 до 1908 рр. імпорт дичини складав лише $2,3 \%$ від експорту. У цей же час спостерігалось збільшення частки імпорту до експорту дичини від 0,8\% у 1884-1888 pр. до 3,8\% у 1904-1908 pр. (Детальніше у таблиці № 1).

Зокрема, у 1896 р. вартість імпортованої мисливської продукції з АвстроУгорщини складала 124646 зол., а експорту - 4027420 зол. Точної статистики про те, яку роль в імпорті та експорті дичини відігравала Галичина, немає, але 3 історичних джерел відомо, що Галичина поставляла до Відня значну кількість кабанів, козуль, оленів, зайців. Відень для Галичини був найбільшим споживачем їі мисливської продукції ${ }^{1}$.

${ }^{1}$ Pawlik S. Handel zwieryzuną, rybami i rakami w Galicyi. Łowiec. 1899. № 1. S. 2-6. 
Експорт-імпорт дичини Австро-Угорщиною (1884-1908 рр.) ${ }^{2}$

\begin{tabular}{|c|c|c|c|}
\hline Роки & $\begin{array}{c}\text { Імпорт дичини } \\
\text { (в коронах) }\end{array}$ & $\begin{array}{c}\text { Експорт дичини } \\
\text { (в коронах) }\end{array}$ & $\begin{array}{c}\text { Співвідношення імпорту } \\
\text { до експорту (у \%) }\end{array}$ \\
\hline $1884-1888$ & 72180 & 8192350 & 0,8 \\
\hline $1889-1893$ & 196565 & 15650034 & 1,2 \\
\hline $1894-1898$ & 420122 & 18823250 & 2,2 \\
\hline $1899-1903$ & 448268 & 15641809 & 2,8 \\
\hline $1904-1908$ & 563946 & 14782864 & 3,8 \\
\hline Всього & $\mathbf{1 7 0 1 0 8 2}$ & $\mathbf{7 3 0 9 0 3 0 7}$ & $\mathbf{2 , 3}$ \\
\hline
\end{tabular}

Визначальним для експортно-імпортних операцій було нормативно-правове забезпечення. Зокрема, в Законі Австрії «Про мито» (1868р.) визначалось, що за імпорт 1 центнера риби слід було сплатити 1,5 золотих, таку ж суму потрібно було сплатити за одну корову. Не обкладались митом телята, свині, коні, дичина ${ }^{3}$. У Законі «Про ввізний митний тариф Австро-Угорщини» від 25 травня 1882 року ставка сплати мита за імпорт 100 кг риби, раків та слимаків становила один золотий, в той час як за 100 кг битого м'яса сплачували 6 золотих, за 1 бика - 4 зол., корову - 3 зол., вівцю 0,5 зол., свиню -3 зол. ${ }^{4}$

Австрійський закон від 13 лютого 1906 року «Про встановлення розміру мита» визначав ставку мита для всіх країн Австро-Угорської імперії. Зокрема, за імпорт 100 кг риби або раків потрібно було сплатити 10 крон. Не обкладалась митом жива дичина - копитні і пернаті. За 100 кг битих пернатих накладалось мито - 25 крон, а за 100 кг живих -8 крон. За 100 кг битої дичини потрібно було сплатити 20 крон. ${ }^{5}$

Тогочасний дослідник торгівлі дичиною, С. Павлік вказував, що одна 3 причин подорожчання м'яса дичини у Відні полягала у правилах експорту, відповідно до яких було встановлено досить високе мито. У Німеччині це мито були меншим, і дичину туди було легше постачати. Також через несприятливу фіскальну політику багато мисливської продукції проходило повз ринок. Так, розмір податку за оленя великого чи малого був однаковим, тому на Львівський ринок потрапляли старі особини, тоді як молодих відправляли на Віденський ринок, де ціни були вищим ${ }^{6}$. Я. Дерезіньский вказував, що живу дичину найлегше було експортувати до Італії, бо за неї не потрібно було сплачувати мито, а італійські торгівельні компанії закуповували ії безпосередньо на кордоні, після чого вона швидкими поїздами протягом 24 годин доставлялась у найвіддаленіше місце країни 7

\footnotetext{
${ }^{2}$ Rożyński F., Schechtel E. Ekonomiczne znaczenie łowiectwa dla naszego kraju. Warzsawa: Nakładem polskiego towarzystwa łowieckeigo, 1921. S. 3.

${ }^{3}$ Przekłady ustaw, rozporządzeń I obwieszczeń z dziennika praw państwa dla Królestwa Galicyi i Lodomeryi, tudzież Wielkiego Księstwa Krakowskiego. Lwów : król. galic. drukarnia rządowa, 1868. S. 137-139.

${ }^{4}$ Dziennik ustaw państwa dla królestw i krajów w radzie państwa reprezentowanych. Wiedeń, 1882. S. 119-130.

${ }^{5}$ Dziennik ustaw państwa dla królestw i krajów w radzie państwa reprezentowanych. Wiedeń, 1906. S. 40.

${ }^{6}$ Kochanowski C. Sprzedaż dziczyzny w mieście Lwowie. Łowiec. 1903. № 22. S. 255-258.

${ }^{7}$ Dereziński J. Możliwości exportu żywej dziczyzny z Polski do Włoch. Łowiec Polski. 1931. № 8. S. 146.
} 
Важливе значення в зовнішньо-торгівельних операціях займала торгівля рибою. Найбільше риби до Австро-Угорської імперії ввозили з Росії. В основному це була свіжа риба. Зокрема, у 1896 році до Австро-Угорської імперії з Росії ввезено риби на суму 988725 золотих, до Румунії - 383175 золотих, Німеччини - 277865 золотих, Італії - 174450 золотих. Основними постачальниками морської риби до Австро-Угорщини були Німеччина, яка в 1896 році поставила товару на суму 913560 золотих, та Італія - на суму 358740 золотих. Найбільше оселедця постачали Англія, Німеччина, Норвегія, Швеція і Нідерланди, тріски - Норвегія, Німеччина, Нідерланди та Італія, інші види риби - Англія, Норвегія, Росія, Румунія, Німеччина. Найбільшим постачальником ікри була Росія ${ }^{8}$.

Для захисту своїх внутрішніх ринків держави застосовували механізми державного регулювання ринку риби. Кожна держава, яка сама виробляла надлишкову продукцію, захищала свої ринки митом від ввезення з інших країн. Так, Німеччина, яка славилась виловом риби з морів та виготовленням оселедців, щоб захистити внутрішній ринок рибної продукції, ввела в 1901 році мито на ввезення до Німеччини 3 Австро-Угорської імперії живих коропів у розмірі 15 марок за центнер риби. Таку звістку експортери риби сприйняли з незадоволенням і зазначали, що такі дії Німеччини спрямовані на знищення рибної галузі Австрії. Більше того, журнал «Окульник», орган Краківського рибальського товариства, розповідав про інформаційну війну, яка вибухнула в Німеччині: «Багато фахових журналів, що виходять у Німеччині, подають фальшиву інформацію про те, що в Галичині розповсюджене інфекційне захворювання коропа, і ввезення його до Німеччини є небезпечним».

Крім високого ввізного мита, запровадженого Німеччиною на рибну продукцію, надзвичайно довгою і забюрократизованою стала процедура проходження митного оформлення, що спричиняло псування риби, яку ветеринарні лікарі бракували і взагалі не пропускали через кордон. Більше того, Німеччина зобов'язала своє консульство у Львові проводити ветеринарну експертизу риби та раків, яких експортували з Галичиния.

Галицькі рибалки шукали вихід із цієї ситуації, переорієнтовуючи продаж риби в інші країни. Лунали пропозиції спорудити за кошт держави консервний завод із переробки риби, бо консервна продукція, що ввозилась з Істрії (Хорватії), мала добрий попит, наприклад, консерви сардин, які в народі називали «москаликами». Але все ж таки найбільші сподівання були пов'язані з тим, що уряд Австрії домовиться з Німеччиною про відміну ввізного мита ${ }^{10}$.

Для врегулювання двостороннього конфлікту, що виник між Австрією та Німеччиною через експорт риби, 21 листопада 1901 року відбулась нарада в центральному австрійському закладі з охорони інтересів рільництва і лісівництва у справі регулювання мита на рибу. На думку всіх присутніх на нараді, мито, встановлене Німеччи-

\footnotetext{
${ }^{8}$ Pawlik S. Handel zwierzyną, rybami i rakami w Galicyi. Łowiec. 1899. № 2. S. 13-16.

${ }^{9}$ Traktaty handlowe. Okólnik. 1900. № 46. S. 5.

${ }^{10}$ Cło od ryb. Okólnik. 1901. № 55. S. 232.
} 
ною, негативно впливало на торгівлю рибою. Було прийнято звернення до Австрійського уряду з вимогою провести переговори щодо скасування мита, а у випадку відхилення Німеччиною цієї пропозиції - запровадити подібні мита на ввезення риби 3 цієї країни. Австрія також вела агітацію щодо повної заборони ввезення замороженої рибної продукції через ії шкідливість для здоров'я, а основним постачальником мороженої продукції була саме Німеччина ${ }^{11}$.

Проте Німеччина не була єдиною у введенні ввізного мита. Слідом за нею рішенням від 26 січня 1903 року Росія також запровадила ввізне мито на рибну продукцію - 27 копійок за пуд риби ${ }^{12}$.

Краківське рибальське товариство виступило 3 ініціативою до уряду, щоб торгівля рибою між Австрією та Німеччиною була вільною. На думку товариства, «потрібно запровадити мито на експорт до Австрії риби з Румунії та Росії, а в майбутньому - з Сербії та Італії. У цих країнах географічні та економічні умови були кращими, ніж в Австрії, тому й риба в них була дешевшою. Гальмом експорту риби 3 Австрії є висока вартість перевезення колією» ${ }^{13}$.

Через загострення ситуації з експортом риби в Німеччині це питання у 1902 році розглядалось на парламентській комісії. В результаті було ухвалене звернення до німецького парламенту, в якому відзначався негативний вплив встановлення Німеччиною мита на рибу ${ }^{14}$. Проте «Німецьке рибальське товариство», обстоюючи власні меркантильні інтереси (недопущення конкуренції на внутрішньому німецькому ринку риби), звернулось до уряду Німеччини з вимогою, щоб мито було підвищене 315 до 25 марок $^{15}$.

Різноманітні мита та податки значно здорожували рибну продукцію. Так, у статті «Чи варто продавати форель у Парижі» (1904р.) детально описані всі ціноутворюючі перипетії на форель. По-перше, щоб продавати рибу на Паризькому ринку, потрібно було навести ділові контакти з тамтешніми торговими представниками. Найбільшим попитом у Парижі користувалась озерна форель ціною від 8 до 13 франків за 1 кілограм, меншим - річкова форель ціною від 5,5 до 8 франків за 1 кг. Якщо у Львові купити 1 кг форелі за 5 франків, то один франк витрачається на різні податки, мита та збори. Крім того, у випадку продажу у Франції риби галицьким риболовам потрібно було сплатити мито за 100 кг риби в розмірі 30 франків у державний фонд, міський акциз - 40 франків, 8\% комісійних - за вартість пересилки. 1\% відсоток риби дорогою всихав і риба зменшувалась у вазі. Порада для торговців містила таку інформацію: кращі торги в Парижі відбувались у п'ятницю, суботу і неділю; найоптимальніше пакувати в посилці по 50 форелей

\footnotetext{
${ }^{11}$ Cło od ryb. Okólnik. 1902. № 57. S. 50.

${ }^{12}$ Cło rosyjskie od ryb. Okólnik. 1903. № 64. S. 164.

${ }^{13}$ Cło od ryb. Okólnik. 1903. № 64. S. 130.

${ }^{14}$ Cło od ryb. Okólnik. 1902. № 59. S. 136.

${ }^{15}$ Cło od ryb. Okólnik. 1902. № 56. S. 7.
} 
до ящика 3 льодом ${ }^{16}$. Наприкінці XIX століття під час різних святкувань гості та мешканці Парижа (3 800000 осіб) з'їли 575 тонн риби, що показує, яким великим попитом користувалась риба ${ }^{17}$.

Для недопущення митних конфліктів в окремих випадках для врегулювання експортно-імпортних відносин укладались міждержавні торгові договори (трактати), які окремо врегульовували розмір мита. Зокрема, торговий трактат від 24 березня 1870 року, укладений між Австро-Угорською монархією та Іспанією, врегульовував питання торгових відносин під час торгівлі рибою ${ }^{18}$. Аналогічний торгівельний договір був укладений між Австро-Угорською монархією та Італією 27 грудня 1878 року та ратифікований Австрією 28 січня 1879 року, а італійською стороною - 30 січня 1879 року. У ньому відзначалось, що сторони домовились про умови торгівлі між країнами, зокрема і про вартість мита на конкретні види товарів. Торгівля свіжою рибою, раками, слимаками проходила без сплати мита, тоді як за торгівлю морською рибою необхідно було сплатити 3 крони за кожні 100 кг. Таку ж суму потрібно було сплатити під час торгівлі свійськими тваринами. Але харчова продукція оподатковувались за вищою ставкою. Так, за переміщення через кордон 100 кг ковбаси мито становило 16 крон, а сиру $-4,4$ крони ${ }^{19}$.

Висновки 3 даного дослідження і перспективи подалыших розвідок у даному напрямку. Узагальнюючи досвід митної політики влади Галичини середини XIX початку XX століття в мисливському та рибальському господарствах, відмічаємо, що мито на рибу було вищими, ніж на свійську худобу, а деякі категорії свійських тварин та живої дичини взагалі не обкладались митом. Встановлено, що мито на м'ясо пернатої дичини було вищим, ніж на м'ясо копитної дичини. Для оперативного врегулювання торгівельних відносин між країнами питання величини мита на дичину та рибу врегульовувались у міждержавних договорах. Рішення щодо розміру митних зборів, на відміну від регулювання рибальського та мисливського господарства, які ухвалювались на провінційному рівні, належали до компетенції уряду Австро-Угорщини. Встановлено, що громадські організації лобіювали перед органами влади введення або відміну митних зборів із метою відстоювання власних інтересів та інтересів місцевих товаровиробників.

\section{Список використаних джерел та літератури:}

1. Ciekawe szczegóły. Gazeta lwowska. 1899, 23 maja. № 250. S. 3.

2. Cło od ryb. Okólnik. 1901. № 55. S. 232.

3. Cło od ryb. Okólnik. 1902. № 56. S. 7.

4. Cło od ryb. Okólnik. 1902. № 57. S. 50.

5. Cło od ryb. Okólnik. 1902. № 59. S. 136.

\footnotetext{
${ }^{16}$ Czy opłaci się przedawać pstrągi do Paryża. Okólnik. 1904. № 71. S. 188.

${ }^{17}$ Ciekawe szczegóły. Gazeta lwowska. 1899, 23 maja. № 250. S. 3.

${ }^{18}$ Dziennik ustaw państwa dla królestw i krajów w radzie państwa reprezentowanych. Wiedeń, 1871. S. 375.

${ }^{19}$ Dziennik ustaw państwa dla królestw i krajów w radzie państwa reprezentowanych. Wiedeń, 1879. S. 69-75.
} 
Модерна доба

6. Cło od ryb. Okólnik. 1903. № 64. S. 130.

7. Cło rosyjskie od ryb. Okólnik. 1903. № 64. S. 164.

8. Czy opłaci się przedawać pstrągi do Paryża. Okólnik. 1904. № 71. S. 188.

9. Dereziński J. Możliwości exportu żywej dziczyzny z Polski do Włoch. Łowiec Polski. 1931. № 8. S. 146.

10. Dziennik ustaw państwa dla królestw i krajów w radzie państwa reprezentowanych. Wiedeń, 1882. S. 119-130.

11. Dziennik ustaw państwa dla królestw i krajów w radzie państwa reprezentowanych. Wiedeń, 1906. S. 40.

12. Dziennik ustaw państwa dla królestw i krajów w radzie państwa reprezentowanych. Wiedeń, 1871. S. 375.

13. Dziennik ustaw państwa dla królestw i krajów w radzie państwa reprezentowanych. Wiedeń, 1879. S. 69-75.

14. Kochanowski C. Sprzedaż dziczyzny w mieście Lwowie. Łowiec. 1903. № 22 S. $255-258$.

15. Pawlik S. Handel zwieryzuną, rybami i rakami w Galicyi. Łowiec. 1899. № 1. S. $2-6$.

16. Pawlik S. Handel zwierzyną, rybami i rakami w Galicyi. Łowiec. 1899. № 2. S. 13-16.

17. Przekłady ustaw, rozporządzeń i obwieszczeń z dziennika praw państwa dla Królestwa Galicyi i Lodomeryi, tudzież Wielkiego Księstwa Krakowskiego. Lwów: król. galic. drukarnia rządowa, 1868. S. 137-139.

18. Rożyński F., Schechtel E. Ekonomiczne znaczenie łowiectwa dla naszego kraju. Warzsawa :Nakładem polskiego towarzystwa łowieckeigo, 1921. $32 \mathrm{~s}$.

19. Traktaty handlowe. Okólnik. 1900. № 46. S. 5. 